\title{
Migratory Movements of Homo Faber: Mapping Fab Labs in Latin America
}

\author{
David M. Sperling ${ }^{1(凶)}$, Pablo C. Herrera ${ }^{2}$, and Rodrigo Scheeren ${ }^{1}$ \\ 1 University of Sao Paulo, Sao Paulo, Brazil \\ sperling@sc.usp.br, rodrigoscheeren@gmail.com \\ 2 Peruvian University of Applied Sciences, Lima, Peru \\ pablo@espaciosdigitales.org
}

\begin{abstract}
The present paper is a mapping study of digital fabrication laboratories in Latin America. It presents and discusses results from a survey with 31 universities' fab labs, studios and independent initiatives in Latin America. The objective of this study is fourfold: firstly, to draw the cultural, social and economic context of implementation of digital fabrication laboratories in the region; secondly, to synthesize relevant data from correlations between organizational structures, facilities and technologies, activities, types of prototypes, uses and areas of application; thirdly, to draw a network of people and institutions, recovering connections and the genealogy of these fab labs; and fourthly, to present some fab labs that are intertwined with local questions. The results obtained indicate a complex "homo faber" network of initiatives that embraces academic investigations, architectural developments, industry applications, artistic propositions and actions in social processes.
\end{abstract}

Keywords: Digital fabrication $\cdot$ Fab labs $\cdot$ Latin america $\cdot$ Mapping

\section{Introduction and Precedents}

What makes us humans is our capacity to make things. From this perspective, for the philosopher Vilém Flusser [1], looking critically to present manufacturing methods is an effective way to think over our time. In the same way, to discover about the past of our species we should dig ruins of factories. If one asks about future scenarios s/he needs to begin by the stage of factories in the future. Flusser projects the factory into the future as a more adaptable place where "the creative potential of homo faber will come into its own" [1], and where he will recognize the action of manufacturing as the same of learning, acquiring information, producing it and disseminating it. It is possible to see these concerns of Flusser about the factories in the future as a previous conception of what we are experiencing nowadays as, despite their differences, maker spaces, hackerspaces and fab labs [2].

Recovering these ideas, this article aims to exhibit the current state of the art of digital fabrication in the field of architecture in Latin America, ${ }^{1}$ looking to its recent

\footnotetext{
${ }^{1}$ For the sake of this paper, Latin America is been represented by countries of the fab labs that answered the survey presented here, with emphasis in South America.
} 
past and to its present, allowing the delineation of future trends. Digital fabrication, one of the last unfoldings of the CAAD field, coexists in Latin America with a context of late and recent industrialization - dated from XX century. It brings new perspectives of innovation to the uneven and combined development in the region, that still has big challenges for economic investment and infrastructure oriented to research.

The present paper is a mapping study of digital fabrication initiatives in Latin America. It presents and discusses some results from a survey performed in 2014 with 31 universities' fab labs, ${ }^{2}$ studios and independent initiatives in Latin America. For Abrams and Hall, mapping "has emerged in the information age as a means to make the complex accessible, the hidden visible, the unmappable mappable (...) mapping refers to a process - ongoing, incomplete and of indeterminate, mutable form." [3].

A previous study about digital fabrication in Latin America has been conducted by Herrera and Juaréz [4], categorizing 18 laboratories under three types of initiatives: experiences of master and doctoral students; external academic/commercial circuit, and self-learning. Mapping was also used before by Rocha [5] for the purpose of delineate a computational emergence in architecture between 1960-80, exposing the role of theory within computational practice, connections and influences of people and universities between UK and USA. The thesis focuses on five research centers both in the UK and in the USA, constructing a broader context to be able to understand a historical scenario that influenced the formation of our contemporary architectonic computational culture [5].

The objective of our study is fourfold: firstly, to draw the cultural, social and economic context of implementation of digital fabrication laboratories in the region; secondly, to synthesize relevant data from correlations between organizational structures, facilities and technologies, activities, types of prototypes, uses and areas of application; thirdly, to draw a network of people and institutions, recovering connections and the genealogy of these fab labs; and fourthly, to present some fab labs that are intertwined with local questions.

\section{Context of the Region}

The development of Latin American fab labs is taking place in a progressive way. In a first stage due to the high costs of equipment of Rapid prototyping the major initiatives were linked with the large industry and to universities and research organizations. With the reduction of costs for acquisition of equipment and the expiration of some patents [4], began to emerge fab labs consolidated at smaller scales and more appropriated for "home users", focused on product design and interdisciplinary practices, of which only recently began to receive greater attention from architects. And, finally, with the growth of the "maker movement" (or DIY), independent initiatives emerged and started to

\footnotetext{
${ }^{2}$ In this paper we use "fab labs" without capitals to differentiate independent laboratories from the Fab Lab network of MIT.
} 
expand [6]. Recently the creation of fab labs became part of the public policy of Latin American cities such as Bogota and Sao Paulo, in the context of "creative cities". 3

Even though the creative inspiration of digital fabrication lab's in our region is effervescent, the scenario is very different from other places in North Hemisphere. The MIT Fab Lab's network installed in South America is an indicative of present challenges in local context. According to Benito Juárez - coordinator of Fab Lab Lima and of the South America MIT Fab Lab's network - actually the network has more than 250 laboratories around the world with an exponential growth in recent years. Despite they present itself as an inclusive project, $75 \%$ of Fab Labs are located in developed countries (40\% in Europe e $35 \%$ in USA) and $25 \%$ in developing countries, with only $5 \%$ in Latin America. Juarez points out that some cultural factors cause that the concept of "technological democratization" - conceived in developed nations - differs from the reality in our region [7].

The first challenge is the extension of the "innovative thinking", inverting the consumer's framework to another about technological development. The second challenge is the substitution of "competitive thinking" for "cooperative thinking", overcoming the win /lose logic present in low degree innovation environments. The third challenge is the optimization of "economic and administrative factors", with cutting rates and bureaucracies to purchase equipment $[7,8]$, besides encouraging local production of machinery and technology.

The local situation in front of the expansion about what is being considered as a new cultural, economic, educational and industrial revolution [9-13] has received a growing interest from the region and from outside of it, in recent articles [4, 8, 14], exhibitions, ${ }^{4}$ a round table, ${ }^{5}$ a thematic symposium ${ }^{6}$ and a lecture. ${ }^{7}$

${ }^{3}$ Prefeitura de SP anuncia 12 Fab Labs em São Paulo [SP City Hall announces 12 Fab Labs in Sao Paulo], Estado de Sao Paulo, February 03, 2015, URL: http://blogs.estadao.com.br/link/prefeiturade-sp-anuncia-12-fab-labs-em-sao-paulo/.

${ }^{4}$ Exhibitions: New Territories: Laboratories for Design, Craft and Art in Latin America, MAD Museum, New York, November 4, 2014 to April 5, 2015, URL: http://madmuseum.org/exhibition/ new-territories; Homo Faber. Digital Fabrication in Latin America, Vila Penteado, Faculty of Architecture and Urbanism of the University of Sao Paulo, upcoming next July as part of CAAD Futures 2015, URL: http://caadfutures2015.fec.unicamp.br/index.php/exhibition1/.

${ }^{5}$ Round table "New Mediums: Digital Fabrication in Latin America", MAD Museum, December 11, 2014, with the designers Guto Requena (Brazil) and Sebastian Errazuriz (Chile), URL: http://www. madmuseum.org/events/new-mediums-digital-fabrication-latin-america.

${ }^{6}$ Thematic Symposium: "Laboratórios de produção digital em arquitetura - experimentações em ensino, pesquisa e extensão no Brasil" [Digital Production Labs in Architecture - teaching, research and extension experiments], coordinated by prof. David M. Sperling (USP, Brazil), in the III Encontro da Associação Nacional de Pesquisa em Arquitetura e Urbanismo [III Encounter of the National Association of Research in Architecture and Urbanism], Sao Paulo, October 20-24, 2014. URL: http://www.anparq.org.br/dvd-enanparq-3/htm/XFramesSumarioST.htm.

${ }^{7}$ Herrera, P.: Towards an Identity: Digital Fabrication in Latin America. Lecture at Symposium AA Visiting School: Politics of Fabrication Laboratory, Valparaíso, Chile, May, 13th (2011). Available at URL: http://issuu.com/pabloherrera/docs/towards_an_identity_digital_fabrication_in_latin_a/1. 


\section{Mapping Latin American Fab Labs}

It is broadly known that the MIT Fab Labs are mapped and their profile is public, ${ }^{8}$ with 39 operating in region: Argentina (7), Brazil (14), Chile (4) Colombia (5), Ecuador (2) and Peru (7). Knowing the existence of several other fab labs that do not participate in this network, the research is directed to them, even it includes three MIT Fab Labs by the representativeness of their work (Brazil: 2; Peru: 1).

In order to capture the institutional profile, infrastructure, operation and activities of these laboratories, we performed a mapping based on a survey using an online form. This survey was submitted in July 2014 to 48 fab labs, of which 31 laboratories from 06 countries answered (Argentina: 2; Brazil: 22; Colombia: 1; Chile: 4; Peru: 1; Uruguay: 1). ${ }^{9}$

The survey was oriented to capture institutional information (name, affiliation, city/ country, current coordinator, current staff, date of foundation, brief history, association with nets, email/website) and infrastructure (machines), operating and work data (summary of current activities/workshops/courses, fabrication technologies, number/ types/brands of equipment, uses of digital fabrication and applications of the fabrication processes/fabricated objects). The possibilities of the multi-choice answer for "uses of digital fabrication" were: "fabrication of architectural components", "fabrication of architectural models", "fabrication of construction molds", "fabrication of machines", "prototyping of small objects", or "others". And for "applications of the fabrication processes/fabricated objects" the multi-choice possibilities were: "design prototypes (visualization and/or simulation and/or analysis)", "pedagogical models", "components for the construction industry", "models for art and museology", "models of historical buildings", "objects for impaired people", "objects /processes for development of communities", "pedagogical objects", or "others".

\footnotetext{
${ }^{8}$ URL: https://www.fablabs.io/map (March 26, 2015).

${ }^{9}$ Argentina: CID - Centro de Informática y Diseño - FADU/Universidad Nacional del Litoral; Instituto de la Espacialidad Humana - Laboratorio de Morfología - FADU/UBA; Brazil: Aleph Zero; CADEP Centro Avançado de Desenvolvimento de Produtos - FAAC/UNESP; Centro de prototipagem experimental - FCT/UNESP; DT3D - Divisão de Tecnologias Tridimensionais Centro de Tecnologia da Informação Renato Archer; Estudio Guto Requena; Fab Lab Universidade de São Paulo - FAU/ USP; Fab Social; Garagem Fab Lab; GEGRADI, Grupo de Estudos para o Ensino/aprendizagem de Gráfica Digital - FAU - UFPel; LAGEAR - Laboratório Gráfico para Experimentação Arquitetônica - FAU/UFMG; Lamo3D - Laboratório de modelos 3D e Fabricação Digital - FAU/UFRJ; LAPAC / Laboratório de Automação e Prototipagem para a Arquitetura e Construção - FEC/UNICAMP; Laboratório de Prototipagem Rápida Mackenzie - FAU/Mackenzie; LEAUD - Laboratório de Estudo das Linguagens e Expressões da Arquitetura, Urbanismo e Design - DAUR/UFJF; LED | Laboratório de Experiência Digital - FAU/UFC; LM + P - Laboratório de Modelos e Prototipagem DA-CT/UFPA; Nomads - IAU/USP; PRONTO 3D - Laboratório de Prototipagem e Novas Tecnologias Orientadas ao 3D - Design/UFSC; Rede Brasileira de Fabricaçao Digital; SimmLab Laboratório de Simulações e Modelamento em Arquitetura e Urbanismo - FAU/UFRGS; SUBdV Architecture; ViD_Virtual Design - Design/UFRGS; Chile: Area Computacional - Universidad Tecnica Federico Santa Maria; gt2P - Great things to people; Lab CNC FAU/Uchile; Producción Digital UC / Fabhaus UC - PUC-Chile; Colômbia: Frontis3D R + D; Peru: Fab Lab Lima; Uruguay: LabFabMVD - FArq/Universidad de la República.
} 


\subsection{Institutional and Infrastructure Profile}

Initially, it is important to note that most of the answers came from Brazilian fab labs (22 of 31) linked to research institutions /universities (15 of 31). Although one participant started his work in the year 2000 (DT3D-CTI Renato Archer - Fig. 1), most of the survey respondents (24) began their work after from 2010. Furthermore, the answers to the survey showed that most fab labs in Latin America were created in the last 3 years (19).

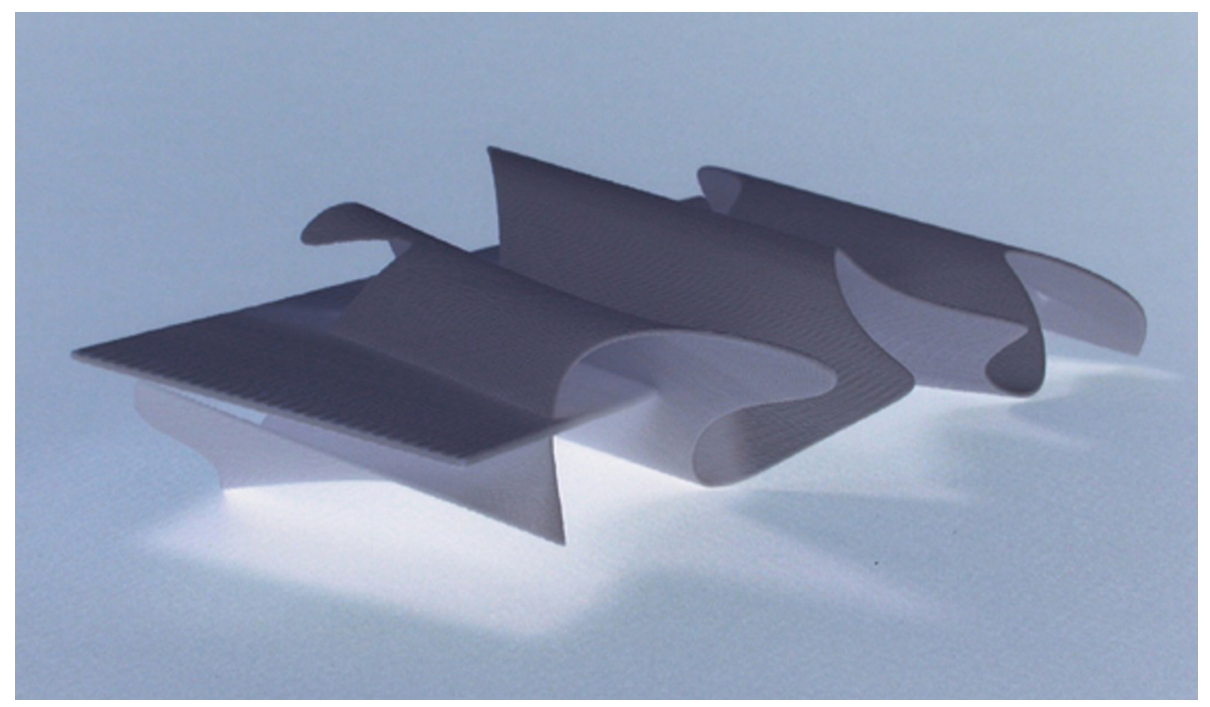

Fig. 1. Surface Homeomorphism. Design by David Sperling, SLS model - DT3D-CTI Renato Archer (2001)

The initiatives were classified according to their legal constitution (academic research institute or private studio), and were evaluated by the capacity of their machinery - variability and quantity - that is, their level of autonomy in manufacturing. So there are two axes and correspondent subdivisions to the installed capacity (Fig. 2).

The first axis, "academic research institutions", marks 22 laboratories that have emerged and operate at universities, technical institutes and research centers. ${ }^{10}$ The first subdivision of the axis, "research and development centers", considers only one facility in Brazil, which has an extensive and diverse rapid prototyping machinery frame (DT3D-CTI Renato Archer, the first fab lab installed in the region ${ }^{11}$ ). The second subdivision refers to "university laboratories with high-capacity installed", which characterizes the initiatives that have at least one of each types of machinery - 3D

\footnotetext{
${ }^{10}$ Into this axis, one institution is bond to MIT Fab Lab and is installed in an university (Fab Lab SP Faculty of Architecture and Urbanism, University of Sao Paulo).

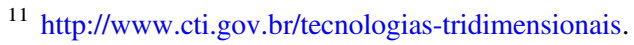


Printer, Laser Cutter, CNC router and /or any other - giving them autonomy in the manufacture of objects. There are 12 fab labs that meet this configuration: 9 in Brazil, 2 in Chile and 1 in Uruguay.

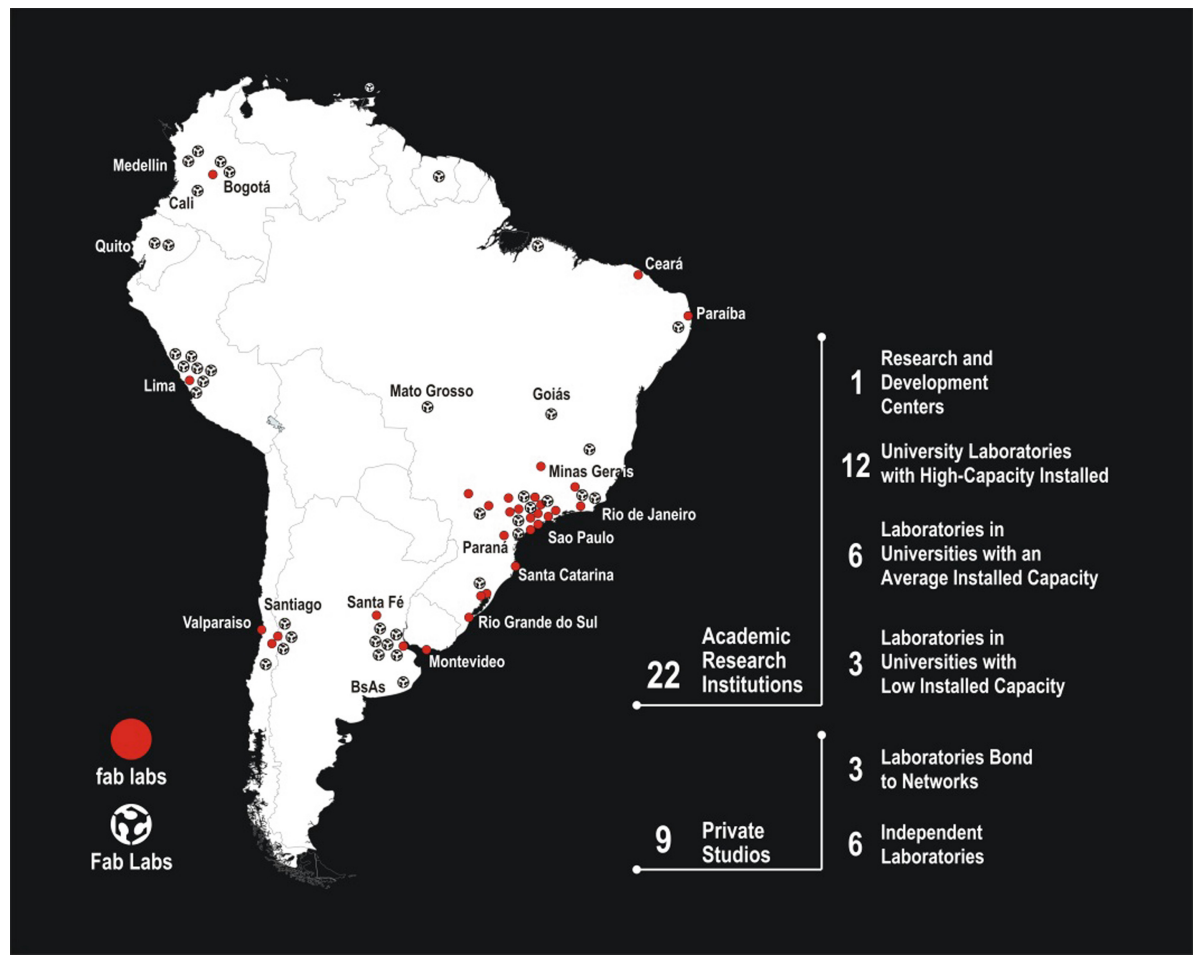

Fig. 2. Map of fab labs mapped and their institutional profile in comparison with the number of MIT Fab Labs in the region.

The third subdivision, "laboratories in universities with an average installed capacity", considers the fab labs that work with only two of the main types of machines 3D Printer, Laser Cutter, CNC Router. There are 6 fab labs in this configuration: 5 in Brazil and 1 in Chile. In the last subdivision, "laboratories in universities with low installed capacity", that characterizes fab labs which have only one type of machine, we mapped 3 initiatives: 2 from Argentina and 1 from Brazil.

The second axis, "private studios", includes 9 labs that were created by the private sector. The first subdivision of the axis, "laboratories bond to networks (FabLab or RhinoFab)" - which requires a minimum of machine framework to receive the label has 3 initiatives: 2 in Brazil and 1 in Peru. Under the second subdivision, "independent laboratories" - that do not have one of the listed equipment or don't have some external link -, 6 initiatives were mapped: 4 in Brazil, 1 in Chile and 1 in Colombia.

Overall, from 31 of the fab labs, 29 have at least one 3D printer; 23 have a laser cutter; 21 have a CNC Router; and 14 have other digital fabrication machines (scanner, vinyl cutter, experimental machine, etc.) and 11 fab labs outsource machinery services. 


\subsection{Workshops and Courses}

All laboratories answered that they provide workshops and courses. While most fab labs are in academic institutions (24) and the emphases of their work are on teaching and research, private studios (7) direct their activities to courses /workshops and to design objects.

Among the synthesized categories, 16 laboratories provide software training and modeling - Rhinoceros 3D, Grasshopper, BIM and CAD software -, 12 provide preparation courses about files for digital manufacturing - F2F -, 7 provide workshops about objects, prototypes and furniture design, 6 about architecture and urban design projects, 2 about programming language and only one provide courses about robotics.

\subsection{Uses of Digital Fabrication}

Within the categories presented in the survey, the uses made of the machinery is firstly oriented to prototyping of small objects ( 31 fab labs), then used to the fabrication of architectural models (27 Labs) and fabrication of architectural components (27 Labs), fabrication of construction molds (15), fabrication of machines (10) and Others (7).

\subsection{Applications of the Fabrication Processes/Fabricated Objects}

From the categories presented in the survey, the following applications have been identified by fab labs, in descending order: design prototypes - visualization and /or simulation and /or analysis (28), pedagogical objects (26), components for the construction industry (16), models for art and museology (16), objects /processes for development of communities (15), models of historical buildings (14), objects for impaired people (10) and others (02).

\subsection{Correlations}

The mapping highlights a recent context of starting and development of fab labs in Latin America. While the first activities started 15 years ago, 2/3 of fab labs were created in the last 3 years. In this scenario, the majority of the fab labs surveyed are bond to academic research institutions and half of them have a high capacity installed. These are followed by fab labs linked to universities or private studios with medium or low capacity.

While the results of "Applications" show, for example, the predominance of the production of small objects in relation to the manufacture of molds for construction or manufacturing machines, the "Uses" results indicate a more equal division in several areas. After the predominance of design prototypes and models for teaching, uses targeted to industry, art and heritage and actions in social process (communities and impaired people) have similar results. 
Fab labs mapped in this survey are geared to a variety of activities involving the training of human resources, design processes and research of different uses and applications of digital manufacturing - with few cases showing a narrow specialization.

\section{Migratory Movements}

The emergence of digital fabrication labs in Latin America countries has happened in very diverse scenarios, initiatives and institutions in recent years. As a migratory movement, its ideas and programs were transmitted from more advanced research centers, with a history of consolidated research - such as North America and Europe to be implemented in Latin America. Therefore, this movement was driven by multiple actors and sources of information, as well as work strategies and funding agencies (Fig. 3).

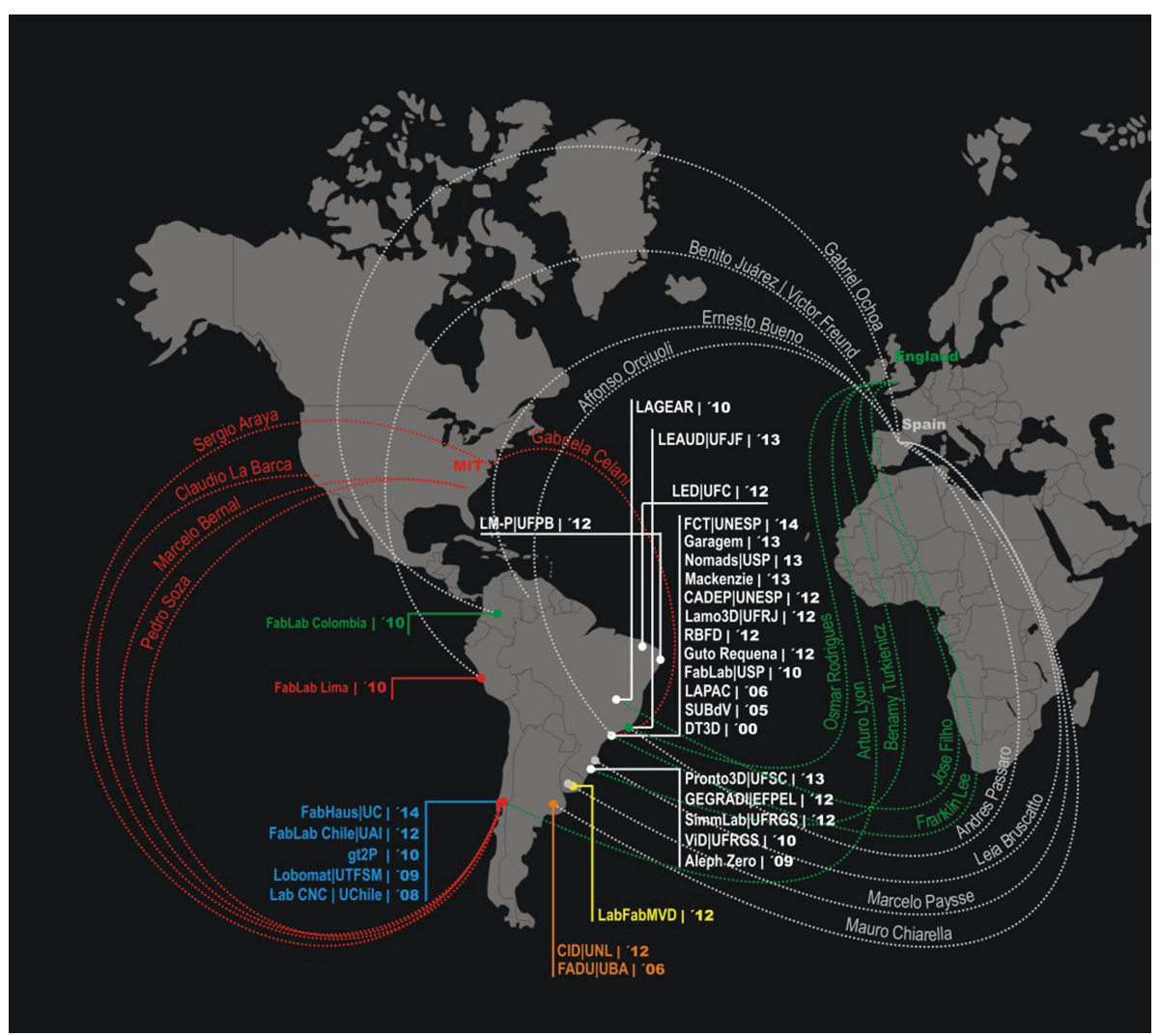

Fig. 3. Map of migratory movements: master and doctoral experiences in USA and Europe and the organization of fab labs. 


\subsection{Global Connections, Local Work and Network}

Two differences mark the implementation of emerging digital technologies, between the northern and southern Hemisphere [15, 16]. While in the former, the use in the profession and self-learning are two recurring patterns, in Latin America, from the beginning these experiences have been part of academic implementations organized in short workshops, gradually forcing the profession to adapt them to their ventures, experimentally.

In a global context, at ABB 2010: Machinic Processes [15], from the 55 professionals and 27 architecture leading architecture schools, Latin America still showed the embryonic state of its process, with no applications that would go beyond the academic context, and no local connection. Neither are there representatives of the region in "Fabricating the Future" [17], which sought to demonstrate the impact of digital manufacturing in professional practice.

Some of the labs mapped in this research appear as early as the $90 \mathrm{~s}$, driven by local academic requirements: in the case of Brazil, a Government act from 1994 determined that all architecture programs were required to teach 'Informatics Applied to Architecture'. Since then, computer labs were created in virtually all architecture schools [18]. However, as shown in the present research, in some cases there 20 years were needed to some of these computer labs go from visualization and simulation to fabrication with 3D printers, $\mathrm{CNC}$ equipment and laser cutters.

Thus, it can be said that during the first years of the 21 st century, the migratory movement of academics and students in Master and Doctorate programs, brought digital technologies to different Latin American universities that were being experimented at the same time in the USA and Europe. Never before Latin America had an approach so disruptive [16] and generalized as in those almost ten first years. Programming and scripting were at the beginning of a phase in which design and fabrication dialogued in the same work platform.

In 2007, Margaret Dewhurst, then a student at AA Intermediate Unit 2 [19], won with "Bad Hair" the Architectural Association Summer Pavilion, adapting a definition created by Guillermo Parada, founder of gt2P [20], that originally produced a Grid Shell or Waffle, to another that allowed to section double-curved surfaces in nonparallel structures.

The immediacy in which information produced in workshops could be shared, allowed local experiences to connect globally with no additional cost, under free platforms such as blogs, websites and repositories. Between 2006 and 2010 the number of new blogs about digital fabrication raised from 7 to 26 in the USA, from 6 to 46 in Europe, and from 1 to 12 in Latin America [21]. This shows the exponential growth in the resources that eliminated previous limitations, such as the need for the people to wait for courses in order to learn about these technologies, as demonstrated by Senske, who wrote that the "technology moves much faster than pedagogy can possibly adapt. Students must often teach themselves in order to keep up with new programs and techniques" [22].

Under these two contexts, after the first decade, the influence of the first academics grew stronger thanks to two simultaneous situations: cheaper 3D equipment [4] 
and the experiences in a local reality that was looking into its own traditions to generate a major impact.

After a first phase of creating labs from experiences of researchers abroad, the current dynamics is an internal nucleation, with expertise sharing between researchers and professionals in the region. This happened, for example, in Brazil as emblematic case. After her PhD at MIT, Gabriela Celani created the Laboratory for Automation and Prototyping for Architecture and Construction (LAPAC) at the University of Campinas (UNICAMP) $^{12}$ in 2006. One of her fomer students, Regiane Pupo, has started to seed a network of labs in the South of the country, creating Rede Pronto 3D, ${ }^{13}$ in 2013. More recently, other former students of Celani have started the creation of a new fab lab in a Northern Federal University (UFRPE).

\section{From Local to Global to Local}

A majority tendency of introduction of fab labs in Latin America - mainly in laboratories linked to universities - can be described by experimentation with design and manufacturing of scale models, objects and pavilions, associating parametric software and laser cutters/CNC. On one hand, the trend has appeared (and is still presented) as a way of learning to use new design tools and production routines. On the other, it can be characterized as a connection with initiatives undertaken before or synchronously in the US and Europe.

After a period of introduction and critical review, this work marked by a strong global accent based on devices (parametric modeling + digital fabrication) is sharing space with initiatives with a local accent based on the technological, cultural and social reality of the region (local reality + parametric modeling + digital fabrication).

These initiatives point to other possible interpretations of modernization and technological development, in front of dual narratives that reinforce relations between developed and developing countries, between center and periphery. And in this sense, they can be approached from studies on the theory of uneven and combined development and their correlation with Latin America, such as the Brazilian sociologist José Domingues, who states that:

\footnotetext{
[ffacing] a homogeneous space-time configuration of global social life and social evolution (...) there are regionalized space-time constructions, with their own rhythms, configurations, densities (...) in a multi-linear evolutionary process in which collective subjectivities exercise their creativity. Those space-time settings can remain in tension with each other, finding themselves now, however, irremediably intertwined and generally subordinated to the dynamic centers that drive modernity. Latin America is one of those space-time constructions - crossed by heterogeneity since its inception' [23].
}

Such initiatives can also be approached from certain aspects of the concept of 'appropriate modernity' developed by Chilean architect Cristian Fernandez Cox as a counterpoint to the vision of a European and American normative modernity

\footnotetext{
12 http://lapac.fec.unicamp.br/.

13 http://www.redepronto3d.com/.
} 
continually being received out of step by Latin America. This notion, conceived during the heat of the debates of the 1980s about a Latin American architectural identity could be recovered to think about the heterogeneous situation of Latin America in the technological context. ${ }^{14}$ Cox defines what it means by 'appropriate modernity':

'Here we find the opportune linguistic coincidence of the triple meaning of the term. Appropriate as adequate. To the reality in question, useful to it, to its service, from it, consistent with it, harmonic with it. Appropriate as made own. (...) In the precisely condition that we make a previous distinction from the critical digestor of our identity, and what suits to our reality, let us know to adapt and harmonically incorporate to it, that is, appropriating it in the sense of make it your own. Appropriate as own. There are peculiarities fairly abundant that are objectively own, and it is only possible to respond with own solutions' [24].

The possibility of other viewpoints for the technological processes in the Latin American hybridization context, such as responses to overcome social challenges and the creation of cultural artifacts, is the result of tactical actions in the face of technologies such as processes of appropriation that may be termed as 'technophagy'. ${ }^{15}$ One could think about these tactical actions according to what has proposed the Czech-Brazilian philosopher Flusser, the action of play by the operator of the apparatus could be a possibility to open the programs that constitute themselves, expanding the playing field:

(...) freedom is a strategy by which chance and necessity are submitted to human intention. In other words, that freedom 'equals playing against the apparatus'. (...) They know that they are playing against the apparatus. However, even they are not aware of the extent of what they are doing. They are not fully aware that they are trying, through their activities, to answer the question of 'freedom' in a context of apparatus' [25].

Of the 31 fab labs mapped in the region, we selected three cases among other possible that work amid the challenges mentioned, from a close bond with the local reality and a tactical view on technology. These fab labs are investigating uses possibilities of digital fabrication to act within social and urban problems in slums (LagearBrasil); to act within social and environmental questions in Amazonia (FabLab-Lima); and to act with cultural and technological hybridization (gt2P).

\subsection{Lagear - Belo Horizonte, Brazil ${ }^{16}$}

In the same way as all installed laboratories in Brazilian public universities, the activities of Lagear (Graphics Laboratory for Architectural Experience - School of

${ }^{14}$ Herrera and Juárez [8] reported to the Argentinian critic of architecture Marina Waisman (La Arquitectura Descentrada, Bogota, Editorial Escala, 1995) which deals with technological modernization processes in the region. The author argues that while for European and American technological modernization happened in response to the circumstances, in Latin America it appears as a symbol of progress and apparent modernity. This is associated to what Cox [16] says about the modernization process in the region carried out from outside and by regulatory pressure, i.e. disconnected from local realities.

${ }^{15}$ We refer here to the concept of 'antropofagia' coined by Oswald de Andrade in the $1920 \mathrm{~s}$, in the context of Brazilian modernist movement, according to which the creation of a genuine national culture would only be possible through the consummation and critical reworking of both culture national and foreign influences.

16 http://www.mom.arq.ufmg.br/lagear/. 
Architecture - Federal University of Minas Gerais) are oriented to teaching, research and extension. Founded in 1993, it is a significant case of the Brazilian context laboratories linked to schools of architecture dedicated to visualization and simulation, which started to work with digital fabrication in recent years, with funding of FINEP, $\mathrm{CNPq}$ and other Brazilian public agencies.

In the 2000s, the research developed in the laboratory about CAD and multimedia practices converged on the possibilities of its application in social contexts, encompassing design and physical computing interfaces such as interfaces to support participatory design processes with residents of social housing complex (Mutirão São Gabriel) and interfaces for community involvement and visualization of urban problems in the scale of the city, the neighborhood and the individual (Ituita).

Under the coordination of the professors José dos Santos Cabral Filho and Ana Paula Baltazar (which had a significant part of their training held in foreign Schools as the University of Sheffield, McGill University, The Royal College and Bartlett School of Architecture) low-cost interactive projects and remote environments connections associated with physical computing systems and simple electronics mechanisms are investigated. In this context, since 2012 the laboratory began to explore parametric design process and digital fabrication.

In reference to cybernetics - as to the ethical imperative of cyberneticist Heinz von Foerster "act always so to increase the number of choices" [26] - the research group works with the focus on social contexts of low income and aims to explore digital fabrication as a way to expand the possibilities to respond to informal architectural issues and complex characteristics of the Brazilian context [27].

One of the works in this line, developed as part of MArch of Marcus V. Bernardo is the use of digital fabrication in housing construction processes in slums - a high precariousness context and reusing materials. Among the adopted initiatives such as the development, availability, sharing and the construction of open source equipment and software, stand out a Grasshopper programming that allows unify the stages of build and cut from the specificity of the collected materials by the locals that have different sizes and the enhancement of a CNC equipment (Fig. 4). It happens with the installation of ultrasonic distance sensors, data projector and camera, to enable feedback in real time between model and equipment, software and machine, preserving the context of high variety [28].

\subsection{Fab Lab Lima - Lima, Peru ${ }^{17}$}

In 2009, Fab Lab Barcelona and the Spanish government, through AECID, chose Lima as headquarters for MIT's first Fab Lab project in Latin America, which included scholarships to Fab Academy (2009-2010). The commitment of each fellow was to return home and lead the implementation. In Lima, Benito Juaréz (architect) and Victor Freund (industrial designer) were selected, and the National University of Engineering, located on the outskirts of Lima, was the venue for infrastructure. Although scholars,

\footnotetext{
17 http://fablabuni.edu.pe/.
} 


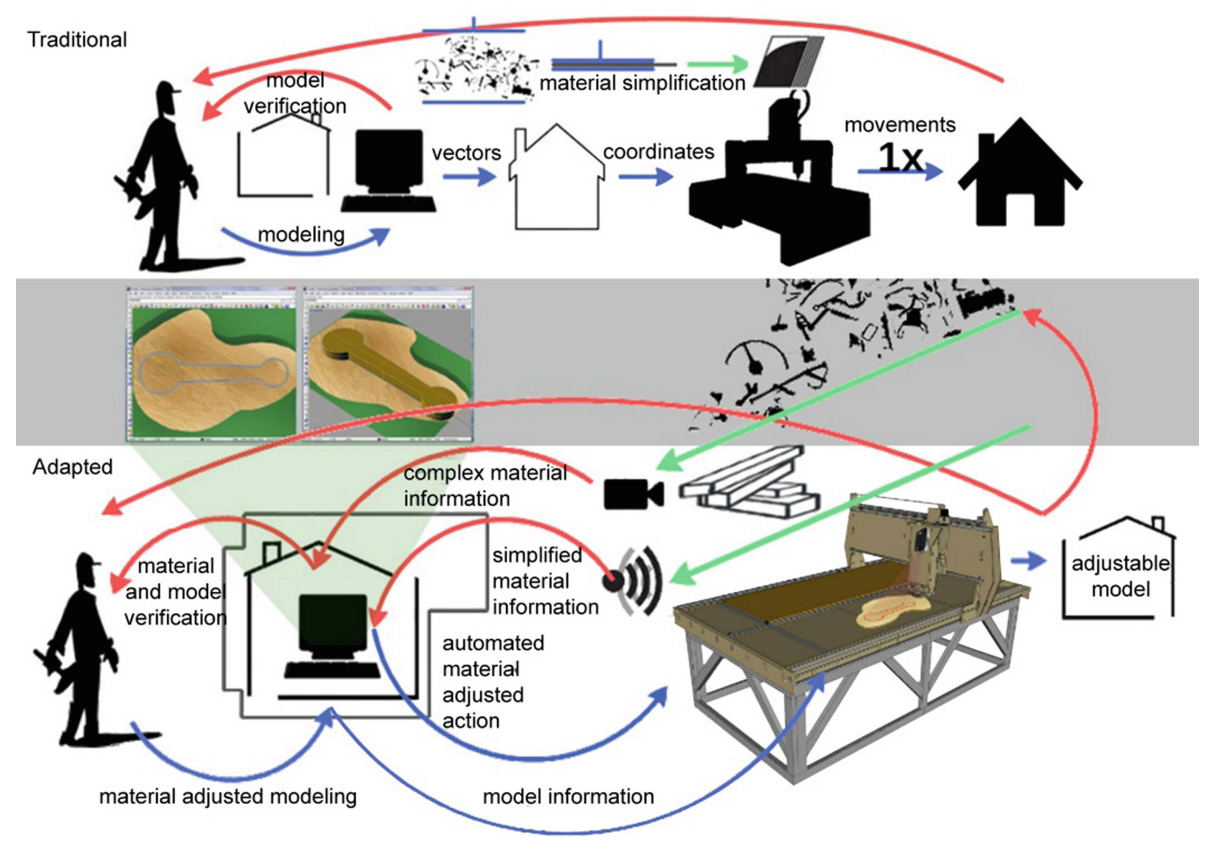

Fig. 4. LAGEAR: feedback improvements and investigation of introduction of a digital fabrication process in auto-construction in slums.

turned into administrators, came back to Lima in 2010, it was not until late 2011, when the Fab7 was performed, that the equipment arrived and it was finally possible to commence operations.

The context of a state university and its geographic location quickly connected it to real situations and, at the same time, limited economic resources. So, from brief workshops, they were able to propose solutions to the common people, recycling or using inexpensive materials. Being an initiative from foreign sources, the academic relationship with professors and students was not direct, the Lab served as a service space for the students, rather than being used for experimentation.

Management was changed in 2012, and the original fellows moved the initiative, still supported by MIT, and founded Fab Lab Met, with funds from the Municipality of Lima. This brought them even closer to projects with a strong cultural, social and environmental link.

Amongst its multiple initiatives, in 2014 the "Fab Lab Floating" project started (Fig. 5), under the Creative Commons License. It seeks to be a repository of ideas for building its infrastructure, and that this in turn promotes the importance of conservation the Amazon region. This region, with a wide variety of resources, many of them still unexplored, is the starting point to explore new materials, reusing waste and propose alternatives aimed at raising the responsibility for our environment. 


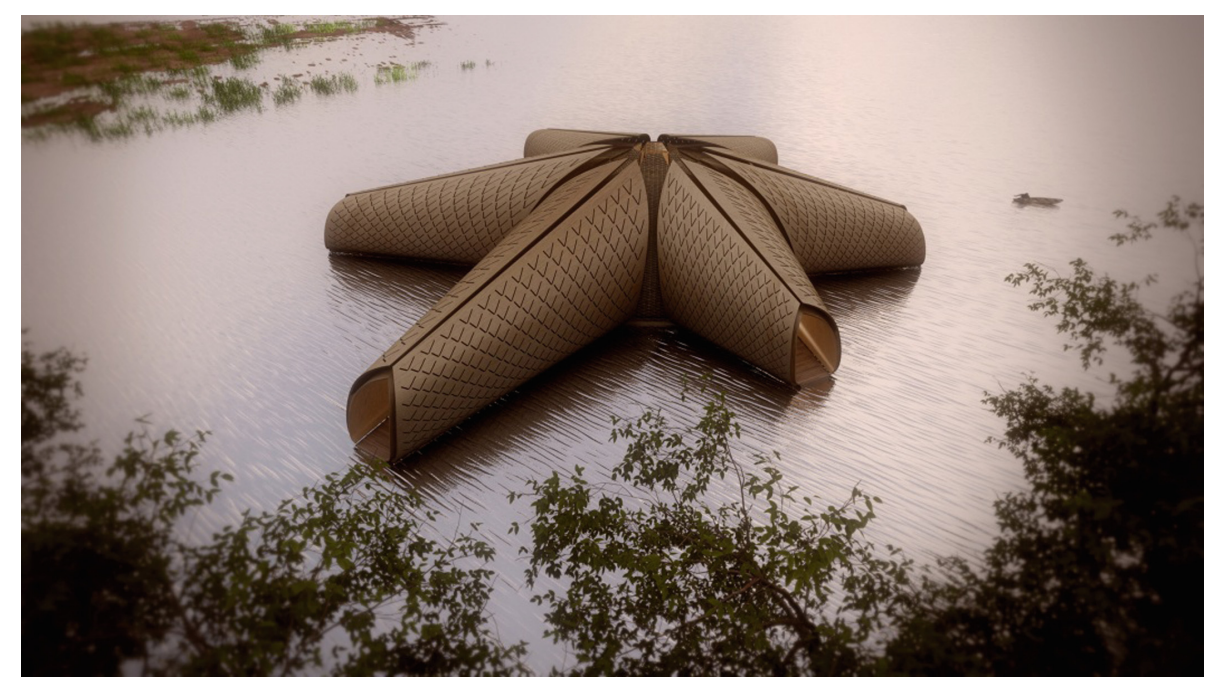

Fig. 5. Fab Lab Lima: Floating Fab as a repository of ideas in the Amazon region.

\section{3 gt2P - Santiago, Chile ${ }^{18}$}

The Higher Education Quality Program (MECESUP) which is in its third phase (20122016) foresees an investment of more than US\$ 80 million in Chilean Universities. Since 1999, this fund has allowed the implementation of digital fabrication equipment in schools of architecture. The case of the Catholic University of Chile (MECESUP 2003), the University of Chile (MECESUP 2008) and UTFSM (MECESUP 2009) have enabled many students to integrate these technologies into their projects, thus providing for its application in the practice of architecture; in other cases, it's just a service for cutting or prototyping.

The self-managed initiatives are also involved in different funding sources, with Santiago de Chile being the first seat of a Mini Maker Faire in Latin America (2012). ${ }^{19}$

Great things to people (gt2P) was founded in 2010 and its current partners are Guillermo Parada, Tamara Pérez, Sebastián Rozas and Eduardo Arancibia. Since before its foundation, their partners' familiarity with programming techniques in Rhinoscripting and later in Grasshopper allowed them to approach to design and fabrication processes. They not only create unique objects, but also focus on solutions that would later become the DNA of a family of products.

\footnotetext{
${ }^{18}$ http://www.gt2p.com/.
}

${ }^{19}$ Maker Faire is one of the four brands promoted by Maker Media, a global platform born with the scope of leading the Maker movement. It focuses on do it yourself (DIY) and/or Do it with others (DIWO). According to Maker Media, "Maker Faire features innovation and experimentation across the spectrum of science, engineering, art, performance and craft." The first Maker Faire took place in San Mateo, CA, in 2006. In 2012 and 2013, Santiago de Chile was the only Latin American proposal and became and important platform for showing the different Fab Labs generated during the last few years. 
Their early works are focused on exploring the variability of shape and fabrication, taking as a starting point G. Parada's experience in the Grid Shell technique, applied to the project "Sectionimal" (coffee table). Afterwards they worked on "Furrow Fields" (centerpiece), "Voro Twins" (shelves) and "Heart Days" (vase). In 2010, gt2P was awarded twice with money by the Technological Innovation Fund of Chile for parametric design and digital fabrication of furniture. In his essays with metal, ceramic and wood, it is evident their aim to interpret the utility of those materials, producing then families like "Supple Series" (aluminium fixation system and bronze 2011) and "Gudpaka" (plywood and alpaca wool 2011).

The group moved its studio in 2011 to a larger space and then experimented with low-tech knowledge, reaching out to the reality of local production. Representative cases are the "Royal Mahuida" (ceramic in bronze 2012), "Vilu Ligth" and "Shhh the hope keeper" (2013), and "Less CPP No. 2: Porcelain vs Lava Lights" (2014). These experiences lead them to implement "Digital Crafting" as a working methodology. The result of these processes lead to the project "Losing My America", currently on display at the Museum of Art and Design in New York. In the latter, they highlight the interpretation of craft and indigenous traditions and the use of 3D scan, FDM printing, Progressive Polygonal Reduction Piece and CNC carving of molds, using different materials like copper, porcelain, ceramic, glass or plaster.

In contrast to the Brazilian and Peruvian examples, gt2P rescues artistic practices powered by technology, experimenting not only with materials and equipment from third parties, but producing their own machines, as in the project "Less No.1 Catenary Pottery Printer" (2014) or distorting the result of an object made by a FDM technology 3D printer, which is incorporated in the process of reading, interpreting, hacking and writing, to produce alterations they called "Dysgraphia" (Fig. 6).
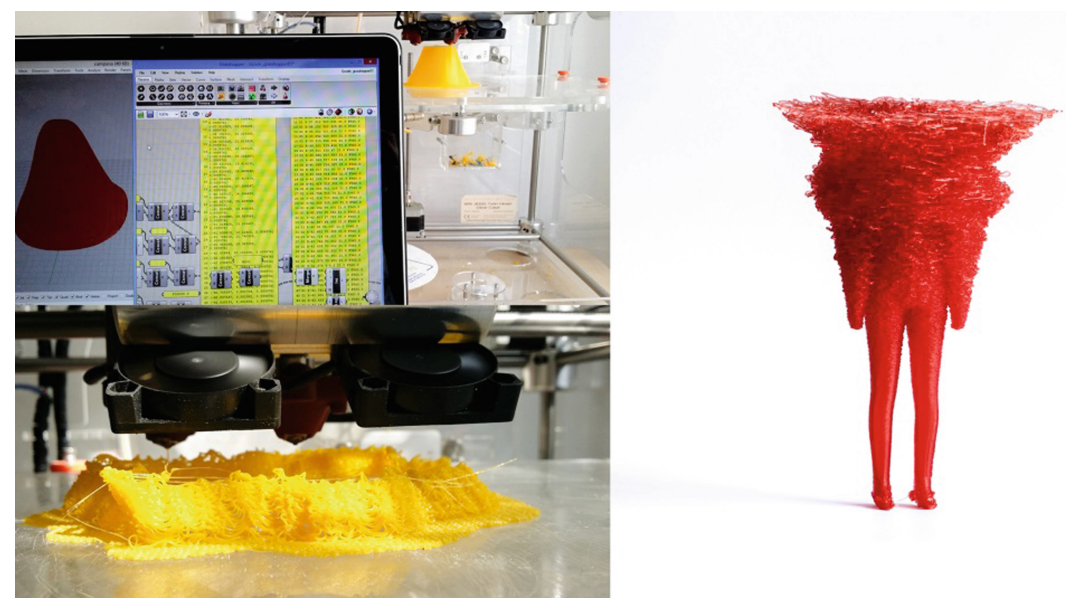

Fig. 6. gt2P: Dysgraphia: "programmed errors" in the language of 3D printers 


\section{Final Remarks}

The set of information synthesized in this research (economic, cultural and social local context, data of existing laboratories, a network of people and institutions, and local cases) indicate the varied "homo faber" network of initiatives of digital fabrication that embraces academic investigations, architectural developments, industry applications, design of objects, artistic propositions and actions in social processes.

Until now, the frame installed in Latin America indicates a double scenario. On the one hand, there is a transition of an initial situation of seeding laboratories from the outside, to a current process of internal nucleation within a context that still has lag in relation to existing infrastructure and human resources in dynamic centers in the area. On the other hand, there is a coexistence of expertise with strong global accent and initiatives in close dialogue with the region's specificities.

In this dialogue with local necessities and potentialities, as shown by the cases presented, we recognize that still reside major challenges and open possibilities to be explored in the future of Latin American fab labs. For this, we imagine that a greater diffusion and acting face to installed practices and the extension of local collaborative networks can be fruitful paths to explore.

Acknowledgements. We thank Gabi Celani (LAPAC-UNICAMP) for the suggestions and comments made during the development of this work.

\section{References}

1. Flusser, V.: The Factory in The Shape of Things. Reaktion Books, London (1999)

2. Van Holm, E.J.: What are Makerspaces, Hackerspaces, and Fab Labs?. http://dx.doi.org/10. 2139/ssrn.2548211. (2015). Accessed 24 Jan 2015

3. Abrams, J., Hall, P. (eds.): Else/where: Mapping. New Cartographies of Networks and Territories, p. 12. University of Minnesota, Minneapolis (2006)

4. Herrera, P.C., Juaréz, B.: Fabrication Laboratories: Problems and possibilities of implementation in Latin America. In: Proceedings of the Fab 9 Research Stream. Yokohama, Keiko University SFC. http://www.fablabinternational.org/fab-lab-research/proceedings-from-thefab-9-research-stream (2013)

5. Rocha, A.J.M.: Architecture theory 1960-1980: emergence of a computational perspective. $\mathrm{PhD}$ Thesis. Massachusetts Institute of Technology (2004)

6. Gaona, N.: Changing the way industries operate is driving force behind maker movement, Future Source Summit, México http://www.futuresourcesummit.com/news/changing-theway-industries-operate-is-driving-force-behind-maker-movement/ (2014)

7. Smith, E.: Benom Juarez on the future of digital fabrication in Peru, make:, April, 24th http://makezine.com/2014/04/24/benom-juarez-on-the-future-of-digital-fabrication-in-peru/ (2014)

8. Herrera, P.C., Juaréz, B.: Perspectivas en los Laboratorios de Fabricación Digital en Latinoamérica. In: Proceedings of the 16th Conference of the Iberoamerican Society of Digital Graphics, SiGraDi, Fortaleza, Brazil, pp. 285-289 (2012)

9. Hatch, M.: The Maker Movement Manifesto: Rules for Innovation in the New World of Crafters, Hackers, and Tinkerers. McGraw-Hill Professional Publishing, New York (2013) 
10. Blikstein, P.: Digital Fabrication and 'Making' in Education: The Democratization of Invention. In: Walter-Herrmann, J., Büching, C. (eds.) FabLab: Of Machines Makers and Inventors, pp. 203-222. Transcript Publishers, Bielefeld (2013)

11. Rifkin, J.: The Third Industrial Revolution How Lateral Power is Transforming Energy, the Economy, and the World. Palgrave Macmillan, New York (2011)

12. Anderson, C.: Makers: The New Industrial Revolution. Crown Publishing Group, New York (2012)

13. Troxler, P.: Making the Third Industrial Revolution - The Struggle for Polycentric Structures and a New Peer-Production Commons in the FabLab Community. In: WalterHerrmann, J., Büching, C. (eds.) FabLab: Of Machines, Makers and Inventors, pp. 181-198. Transcript Publishers, Bielefeld (2013)

14. Celani, G.: Digital Fabrication Laboratories: Pedagogy and Impacts on Architectural Education. Nexus Netw. J. 14, 469-482 (2012)

15. Leach, N., Weiguo, X.: Machinic Processes: Architecture Biennial Beijing 2010. Tsinhua University, Shangai (2010)

16. Herrera, P.C.: Tecnologías Disruptivas: Programación y Fabricación en Latinoamérica. In: Proceedings of the 14th Conference of the Iberoamerican Society of Digital Graphics, SiGraDi, Bogotá, Colombia, pp. 213-216 (2010)

17. Yuan, P.F., Leach, N.: Fabricating the Future. Tongji University Press, Shangai (2012)

18. Soares, L.: EduCAAD: An X-ray of CAAD education in Brazil. In: Proceedings of the 16th Conference of the Iberoamerican Society of Digital Graphics, SiGraDi, Fortaleza, Brasil, pp. 255-258 (2012)

19. Self, M., Walker, Ch.: Making Pavilions: AA Intermediate Unit 2 2004-09. Architectural Association, London (2011)

20. Herrera, P.C.: VBScritp en la educación del arquitecto: Estrategias y métodos durante y después de la implementación In: Proceedings of the 12th Conference of the Iberoamerican Society of Digital Graphics, SiGraDi, La Habana, Cuba, 368-371 (2008)

21. Herrera, P.C.: Rhinoscripting y Grasshopper a través de sus instructores: Un estudio de Patrones y usos. In: Proceedings of the 15th Conference of the Iberoamerican Society of Digital Graphics, SiGraDi, Santa Fé, Argentina, 179-182 (2011)

22. Senske, N.: Fear of Code: An Approach to integrating Computation with Architectural Design. MSc Thesis. Massachusetts Institute of Technology (2005)

23. Domingues, J.M.: A América Latina e a modernidade contemporânea: uma interpretação sociológica, Belo Horizonte, Editora UFMG (2009)

24. Cox, C.F.: Modernidad y Postmodernidad en América Latina, Bogotá, Escala (1991)

25. Flusser, V.: Towards a Philosophy of Photography. Reaktion Books, London (2000)

26. Poerksen, B.: Ethics of enabling ethics. Cybernetics Human Knowing (Exeter: Imprint Academic) 18(3-4), 143-149 (2011)

27. Cabral, F.J.S., Baltazar, A.P.: Por uma produção arquitetônica interativa para além do paradigma da representação: a experiência do LAGEAR. In: Anais do III ENANPARQ 2014, São Paulo (2014)

28. Bernardo, M.V., Cabral F., J.S.: Fabricação digital e variedade fora do contexto industrial. In: Proceedings of the 18th Conference of the Iberoamerican Society of Digital Graphics: Design in Freedom, pp. 320-323 [=Blucher Design Proceedings, v.1, n.8]. Blucher, São Paulo (2014) 